\title{
Physical and Quality Characteristics of Jupi Pineapple Fruits on Macronutrient and Boron Deficiency
}

\author{
Maria José Mota Ramos ${ }^{1}$, Leandro Glaydson da Rocha Pinho² \\ ${ }^{1}$ Research Regional Center and Tecnology Transfer of EMPAER/MT, Várzea Grande, Brazil \\ ${ }^{2}$ Federal Institute of Education, Espírito Santo, Campus Itapina, Brazil \\ Email: "
}

Received 25 April 2014; revised 26 May 2014; accepted 7 June 2014

Copyright (C) 2014 by authors and Scientific Research Publishing Inc.

This work is licensed under the Creative Commons Attribution International License (CC BY). http://creativecommons.org/licenses/by/4.0/

\section{(c) (7) Open Access}

\section{Abstract}

The deficiencies of mineral elements, change the development of plants in a broad sense, and therefore may alter the growth and fruit quality. The objective of this work was to evaluate the influence of macronutrient and boron deficiencies on morphological characteristics of "Jupi" pineapple fruits. The treatments complete, $-\mathrm{N},-\mathrm{P},-\mathrm{K},-\mathrm{Ca},-\mathrm{Mg}$, $-\mathrm{S}$ and $-\mathrm{B}$ were applied as nutrient solutions in plastic pots with $14 \mathrm{~kg}$ of purified beach sand and one pineapple plant as the experimental unit. The trial was set up a randomized complete blocks design with six replicate. Nitrogen deficiency reduced fruit mass with and without crown, fruit length and diameter and peduncle diameter, increased TA, TSS and vitamin C, reduced TSS/TA, pH, pulp coloration and sensory acceptance of the fruits; phosphorus deficiency reduced fruit mass with and without crown, fruit and crown length, potassium deficiency reduced fruit mass with and without crown, length and diameter peduncle and calcium deficiency reduced peduncle diameter. Peel thickness was not affected by any deficiency. Nitrogen is the nutrient that most influenced the fruits quality of pineapple “Jupi”.

\section{Keywords}

Fruit Quality, Nutrient Solution, Fruit Mass

\section{Introduction}

The participation of Brazil in the external market of pineapple is small, despite being a typical fruit of tropical and

${ }^{*}$ Corresponding author. 
subtropical regions, and the country sustain the second largest world production [1]. However, in order to gain competitiveness in foreign markets it requires the provision of fruit of excellent quality. The cultivars planted in Brazil are the Pérola and Smooth Cayenne. Jupi is resembles the "Pérola", which differs by cylindrical format of the fruit. The cylindrical form of the fruits gives that cultivar greater preference as industrial raw material for processing slices in syrup, for increased yield.

Climatic conditions, stages of ripening, varietal differences, mineral nutrition of plants, among other factors, influence sharply in physical characteristics and physical-chemical properties of pineapple.

The effects of nutritional deficiencies in size and quality of pineapple fruit are very variable and depend on mineral nutrient in question and the time when the deficiency symptoms appear. The fruit quality is in part attributed to physical characteristics responsible for external appearance, among which stand out the fruit's size and shape and coloration of the shell, characteristics that constitute the first factor of acceptability of fruits by consumers [2]. The external appearance is the agent of quality of greater influence in the purchase of a product by the consumer, by reason of the association of the appearance of the fruit with edible quality.

Nitrogen typically increases the size and the weight of the fruit of pineapple [3]-[5] reported increased fresh fruit with and without crown with increasing doses of NPK. It was also noticed by [3] the influence of potassium on the diameter of the fruit. The importance of potash on fruit quality is based on its role as promoter of the synthesis of photosynthates and their transport to fruits, grains, tubers and plant storage organs, increasing the conversion of starch, protein, vitamins, oils, and others [6].

The TSS/TA is one of the best ways to evaluate the flavor, being more representative than the isolated measurement of sugar or acidity, providing good idea of balance between these two components [7].

One of the impediments to the growth of cultivated area of cv. Jupi has been the shortage of technical information, especially relating to nutrition and fertilization of culture, which can directly affect the quality of the fruit. The objective of this work was to evaluate the influence of macronutrients and boron deficiencies on the physical and quality characteristics of pineapple cv. Jupi.

\section{Materials and Methods}

The experiment was set up in a greenhouse in Campos dos Goytacazes, RJ, on abril 15, 2004, using plantlets of "Jupi" pineapple obtained by tissue culture. It's consisted of eight treatments: Complete, -N, -P, -K, -Ca, -Mg, $-\mathrm{S}$ and $-\mathrm{B}$, distributed a randomized complete block design, with six replications. The experimental unit was represented by one plant placed into a plastic pot containing $14 \mathrm{~kg}$ of beach sand previously purified by soaking it with pure water until stable $\mathrm{pH}$ of 5.0 followed by a final wash with deionized water. The purification consisted of the soak of the sand with hydrochloric acid diluted in water in the proportion of 1:4 during about four hours, in plastic container of 60 liters and subsequent wash with pure water until that the $\mathrm{pH}$ was stabilized in close value of 5 , when, then, it was made a final wash with deionized water.

Plantlets had an average size of $10 \mathrm{~cm}$. From planting each pot received $500 \mathrm{ml}$ of deionized water every other two days for 15 day, when new roots began to be emitted. From then each pot was supplied three times per week with $500 \mathrm{ml}$ of the complete nutrient solution that presented the following composition, in $\mathrm{mg} \cdot \mathrm{L}^{-1}$ :

$\mathrm{N}\left(\mathrm{NO}_{3}^{-}\right)=112 ; \mathrm{N}\left(\mathrm{NH}_{4}^{+}\right)=3.5 ; \mathrm{P}=7.74 ; \mathrm{K}=156.4 ; \mathrm{Ca}=80 ; \mathrm{Mg}=24.3 ; \mathrm{S}=32 ; 0 ; \mathrm{Cl}=1.77 ; \mathrm{Mn}=0.55 ; \mathrm{Zn}=$ $0.13 ; \mathrm{Cu}=0.03 ; \mathrm{Mo}=0.06 ; \mathrm{B}=0.27 ; \mathrm{Fe}=2.23$ with $\mathrm{pH}=5.5$. From 50 days after the beginning of the application of the complete solution or 65 days after planting, the -B treatment was started to be applied. The other treatments continued to get the complete solution up to 105 days after planting.

Thereafter the macronutrientes concentration of macronutrients was reduced to $10 \%$ of the complete solution and from 150 days after planting, the treatments $-\mathrm{N},-\mathrm{P},-\mathrm{K},-\mathrm{Ca},-\mathrm{Mg}$ and $-\mathrm{S}$ started to be fully applied. At 240 days after planting, the plants of the- $\mathrm{N}$ treatment presented very severe symptoms of deficiency. Therefore they received a nutrient solution with $10 \%$ of $\mathrm{N}$ of the complete solution for a period of four weeks in order, to reduce the risk of absence of fruit formation by these plants. The volumes of nutrient solution applied varied with plant age, from $500 \mathrm{ml}$ up to 150 days after planting; to $700 \mathrm{ml}$ from 150 days to 330 days after planting and finally $1 \mathrm{~L}$ until harvest, applied three times a week.

At eight months after planting flowering forcing was done by applying of $50 \mathrm{~mL}$ solution of Ethrel $0.1 \%$, urea $2 \%$ and calcium hydroxide $0.035 \%$ into the central rosette of each plant [3].

Fruits were harvest at the stage of $75 \%$ yellow rind, from 03/31/2005 to 05/02/2005. Fresh medium weight were determined from the fruit without crown through a digital scale, length of the fruit and peduncle with 
graduated ruler with precision of $1 \mathrm{~mm}$ and peduncle diameter with digital pachymeter . The firmness of the fruit was evaluated at 10 different spots, covering the median portion of the fruit, by means of a penetrometer; the juice content (\%), the percentage ratio between the mass and the fruit juice. The pulp coloration was determined using the median cross-section of the fruit with the scales of notes adapted from [3]. The titratable Acidity (TA), total soluble solids (TSS), $\mathrm{pH}$ and vitamin $\mathrm{C}$ were determined in sample of juice extracted from fruit longitudinal diagonal section, which accounted for a quarter of each of their upper and lower halves. The TA was obtained by titration with sodium hydroxide $0.71 \mathrm{n}$, expressed in \% of citric acid (g/100 ml of juice); the total soluble solids (Brix) were determined by refractometry using a Refractometer Abbe manual; the $\mathrm{pH}$ of the juice was determined by a digital ph meter and relationship TSS/TA was obtained by dividing the total soluble solids values for percentage of acidity. The vitamin C (mg of Ascorbic acid/100 ml of juice) was determined by titration of the juice with 2.6 solution-dichlorophenol-indophenol, sodium salt.

The concentration of N, P, K, Ca, Mg, S and B in the dry matter of "D" leaf were determined at 5, 7, 9 and 12 months after planting according to the methodology of [8], modified by Monnerat S/D.

Data obtained were submitted to the variance analysis and averages of the treatments under deficiency were compared with those of the complete nutrient treatment by the test of Dunnet at $5 \%$. The SAEG programme was used for statistical analysis.

\section{Results and Discussions}

\subsection{Fresh Weight of Fruits with and without Crown}

The N, P and K deficiencies decreased the fruit weight with and without crown (Table 1). The N deficiency reduced fruit weight with crown by $57.59 \%$, P by $26.78 \%$ and $\mathrm{K}$ by $22.8 \%$. N, P and K concentrations at 9 months after planting, (inflorescence appearance time) was 59.5\%, 59.7\% and $78.6 \%$ lower than the one of the complete nutrient treatment, respectively and to 12 months was $68.9 \%$ and $60.6 \%, 94.5 \%$ lower (Table 2).

Working pineapple Jupi [5] observed significant quadratic response effect for fresh mass from fruit of CV. Jupi, with and without Crown depending on doses of NPK. Another author [9] also observed quadratic effect of increasing doses of $\mathrm{N}$ and $\mathrm{K}$ in increasing fresh mass pineapple MD-2. The influence of $\mathrm{K}$ in the productive characteristics of pineapple can be related mainly to his role in photosynthesis. The $\mathrm{N}$ is the nutrient responsible for increased productivity of pineapple, and your deficiencies changes negatively the growth, output and quality of fruit [3] [10] [11].

Fruits of plants cultivated in complete nutrient solution reached average fruit weight of $1594 \mathrm{~kg}$ (Table 1). The average of fruit weight with crown was below those (1.78 kg) obtained by [12]. Second [13], the weight consi-

Table 1. Effect of macronutrients and boron deficiencies on fruit fresh weight (FFW), with and without crown, length and diameter of "Jupi” pineapple fruit.

\begin{tabular}{ccccc}
\hline Treatments & FFW with crown & FFW without crown & Length & Diameter \\
\hline & \multicolumn{2}{c}{ Kg } & Cm & 11.8 \\
Complete & 1.594 & 1.452 & 18.1 & $9.2-$ \\
$-\mathrm{N}$ & $0.676-$ & $0.532-$ & $11.1-$ & $10.7 \mathrm{~ns}$ \\
$-\mathrm{P}$ & $1.167-$ & $1.069-$ & $12.0-$ & $10.7 \mathrm{~ns}$ \\
$-\mathrm{K}$ & $1.231-$ & $1.062-$ & $14.3 \mathrm{~ns}$ & $10.8 \mathrm{~ns}$ \\
$-\mathrm{Ca}$ & $1.613 \mathrm{~ns}$ & $1.482 \mathrm{~ns}$ & $12.7 \mathrm{~ns}$ & $10.7 \mathrm{~ns}$ \\
$-\mathrm{Mg}$ & $1.538 \mathrm{~ns}$ & $1.404 \mathrm{~ns}$ & $13.5 \mathrm{~ns}$ & $12.0 \mathrm{~ns}$ \\
$-\mathrm{S}$ & $1.496 \mathrm{~ns}$ & $1.333 \mathrm{~ns}$ & $15.2 \mathrm{~ns}$ & $10.7 \mathrm{~ns}$ \\
$-\mathrm{B}$ & $1.744 \mathrm{~ns}$ & $1.580 \mathrm{~ns}$ & $12.3 \mathrm{~ns}$ & 5.0 \\
$\mathrm{CV}$ & 12.8 & 14.1 & 1.5 & \\
\hline
\end{tabular}

In each collumn, means followed by + , - or ns either are larger, smaller than the one of the complete treatment, according to Dunnett's test at $5 \%$ level. 
Table 2. Leaf nutrient concentration in dry matter of "D" leaf, in complete and deficient treatment, in four times sampling.

\begin{tabular}{|c|c|c|c|c|c|c|}
\hline \multirow{3}{*}{ Nutrients } & \multirow{3}{*}{ Treatments } & \multicolumn{4}{|c|}{ Times } & \multirow{3}{*}{ CV $(\%)$} \\
\hline & & \multicolumn{4}{|c|}{ Months after planting } & \\
\hline & & Five & Seven & Nine & Ten & \\
\hline \multicolumn{7}{|l|}{ Nitrogen } \\
\hline \multirow[t]{2}{*}{$\left(\mathrm{g} \cdot \mathrm{kg}^{-1}\right)$} & Complete & 16.3 & 16.9 & 18.6 & 17.4 & 6.10 \\
\hline & $-\mathrm{N}$ & $9.22-$ & $6.97-$ & 7.58- & 6.86- & \\
\hline \multicolumn{7}{|l|}{ Phosphorus } \\
\hline \multirow[t]{2}{*}{$\left(\mathrm{g} \cdot \mathrm{kg}^{-1}\right)$} & Complete & 1.68 & 1.62 & 1.39 & 1.03 & 10.0 \\
\hline & $-\mathrm{P}$ & $1.31-$ & $0.97-$ & $0.56-$ & $0.32-$ & \\
\hline \multicolumn{7}{|l|}{ Potassium } \\
\hline \multirow[t]{2}{*}{$\left(\mathrm{g} \cdot \mathrm{kg}^{-1}\right)$} & Complete & 27.7 & 25.5 & 28.5 & 27.25 & 8.9 \\
\hline & $-\mathrm{K}$ & 18.3- & $14.0-$ & $6.10-$ & $1.50-$ & \\
\hline \multicolumn{7}{|l|}{ Calcium } \\
\hline \multirow[t]{2}{*}{$\left(\mathrm{g} \cdot \mathrm{kg}^{-1}\right)$} & Complete & 4.33 & 4.96 & 5.61 & 10.38 & 10.6 \\
\hline & $-\mathrm{Ca}$ & 2.61- & $1.43-$ & $1.34-$ & $1.67-$ & \\
\hline \multicolumn{7}{|l|}{ Magnesium } \\
\hline \multirow[t]{2}{*}{$\left(\mathrm{g} \cdot \mathrm{kg}^{-1}\right)$} & Complete & 1.84 & 2.41 & 2.34 & 3.42 & 17.0 \\
\hline & $-\mathrm{Mg}$ & $1.11-$ & $0.98-$ & $0.47-$ & $0.57-$ & \\
\hline \multicolumn{7}{|l|}{ Sulphur } \\
\hline \multirow[t]{2}{*}{$\left(\mathrm{g} \cdot \mathrm{kg}^{-1}\right)$} & Complete & 1.34 & 1.37 & 1.28 & 1.59 & 12.1 \\
\hline & $-S$ & $1.09-$ & $1.05-$ & $0.65-$ & $0.37-$ & \\
\hline \multicolumn{7}{|l|}{ Boron } \\
\hline \multirow[t]{2}{*}{$\left(\mathrm{mg} \cdot \mathrm{kg}^{-1}\right)$} & Complete & 23.9 & 23.2 & 33.2 & 44.4 & 6.5 \\
\hline & $-B$ & $12.6-$ & $9.74-$ & 7.20- & $4.50-$ & \\
\hline
\end{tabular}

In each column and each nutrient, means followed by - are significantly smaller than the complete treatment according to Dunnett's test at $5 \%$ level.

dered great for pineapples of cv. Perola is between 1.0 - $1.4 \mathrm{~kg}$; According to the classification by weight [14], the fruit from the plant that received the complete solution and deficient in K (Table 1) would be covered in class 3 and 2, respectively and from plants deficient in $\mathrm{N}$ and $\mathrm{P}$ (Table 1 ) in class 1 reaching lowest value on the market. The difference in weight between fruit provides an additional significant financial gain for the producer, when pineapple is marketed as in natura.

\subsection{Fruit Length and Diameter}

The fruit length was reduced by $\mathrm{N}$ and $\mathrm{P}$ deficiencies and the diameter by $\mathrm{N}$ deficiency (Table 1). The $\mathrm{N}$ deficiency reduced the length in $38.7 \%$ and the $\mathrm{P}$ in $33.7 \%$; the fruit diameter was reduced by the $\mathrm{N}$ deficiency in $22 \%$.

The fruit diameter of $11.8 \mathrm{~cm}$ (Table 1) was similar to that found by [13] for the "Pérola", it was $11.2-11.3 \mathrm{~cm}$, but the length of $18.1 \mathrm{~cm}$ was slightly above found by this author.

The average of the fruit length and diameter, in complete treatment were similar to that found by [15] in their work with the cv. Pérola whose length varied from 14 to $19.6 \mathrm{~cm}$, and diameter of $10.31 \mathrm{~cm}$ to $11.05 \mathrm{~cm}$, however, the length was above the value of $15.7 \mathrm{~cm}$ for cv. Smooth Cayenne and $16.1 \mathrm{~cm}$ from cv. Pérola [16].

Reducing the fruit weight caused by deficiencies resulted mainly from the reduction in the fruit length. In the $\mathrm{N}$ case referred to was, also, the smaller fruit diameter, reason why this was the deficiency that caused further reduction of fruit weight. 


\subsection{Crown Length and Weight}

P deficiency reduced the crown length but the weight was not affect by the deficiencies studied (Table 3). The crown length accepted quality standards varies according to the fruits class for export [17].

In pineapple "Queen Victoria" was also found a decrease in fruit crown weight with the reduction in the levels of $\mathrm{N}[18]$.

The fruit crown length from the complete solution is below 1.5 times the fruit length as [17]. Fruits in nitrogen deficient plant presented the crown within the medium considered patterns to "Pérola" of $6.96 \%$ of the fruit weight, as [19]. It's probably that larger values for the crown length have been obtained by applying the complete solution containing nitrogen until the fruit harvest.

\subsection{Peduncle Length and Diameter}

The peduncle diameter was reduced by the shortcomings of $\mathrm{N}$ and $\mathrm{K}$ in $16.7 \%$ and $14.3 \%$ respectively and length by $\mathrm{K}$ and Ca deficiency in $\mathbf{1 7 . 5 \%}$ and $15.1 \%$ respectively (Table 3 ).

Peduncle with smaller diameter may contribute to increase pineapple fruit drop what usually affect its quality and increases its sunburn susceptibility.

\subsection{Fruit Peel Thickness}

There was not influence of nutritional deficiency in the peel thickness (Table 3).

It is likely that there has been a selective allocation of photosynthates in the bark as evolutionary strategy aiming to guarantee reproduction in environments poor in nutrients.

\subsection{TSS (Brix), TA e TSS/TA}

The $\mathrm{N}$ deficiency increased TA in $85 \%$, in the TSS in $11.2 \%$ and relationship TSS/TA. The S deficiency only increased the TSS in $12.5 \%$ (Table 4). At the time of fruit ripening the $\mathrm{N}$ concentration was $60.6 \%$ less than the full treatment (Table 2).

It is likely that the increase of TSS in the fruits, the treatment either by reducing the -S synthesis of sulfurous amino acids causing reduction of protein synthesis and accumulation of soluble carbohydrates. Plants grown under deficiency of $\mathrm{N}$ may have reduced production of amino acids and consequently protein providing greater amount of photosynthates to be used in the accumulation of other organic acids mainly in the synthesis of secondary metabolism compounds such as organic tricarboxylic acid cycle [20].

For brix and acidity of the fruit, the responses to $\mathrm{N}$ were observed by [13] [21] who found a negative correlation for N. Discordant result was found by [8] who reported increased levels of brix and acidity of fruits of cv. Jupi

Table 3. Effect of macronutrients and boron deficiencies on crown length and weight peduncle length and diameter, and peel thickness of Jupi pineapple fruits.

\begin{tabular}{cccccc}
\hline \multicolumn{2}{c}{ Crown } & \multicolumn{2}{c}{ Peduncle } & Peel thickness \\
\hline Treatments & Length & Weight & Length & Diameter & \\
\hline & Cm & Kg & & Cm & Mm \\
\hline Complete & 24.6 & 0.142 & 38.4 & 2.09 & $2.29 \mathrm{~ns}$ \\
$-\mathrm{N}$ & $22.1 \mathrm{~ns}$ & $0.144 \mathrm{~ns}$ & $36.8 \mathrm{~ns}$ & $1.74-$ & $2.19 \mathrm{~ns}$ \\
$-\mathrm{P}$ & $18.3-$ & $0.098 \mathrm{~ns}$ & $34.5 \mathrm{~ns}$ & $2.09 \mathrm{~ns}$ & $2.50 \mathrm{~ns}$ \\
$-\mathrm{K}$ & $27.4 \mathrm{~ns}$ & $0.169 \mathrm{~ns}$ & $31.7-$ & $1.79-$ & $2.24 \mathrm{~ns}$ \\
$-\mathrm{Ca}$ & $21.7 \mathrm{~ns}$ & $0.131 \mathrm{~ns}$ & $32.6-$ & $2.09 \mathrm{~ns}$ & $2.31 \mathrm{~ns}$ \\
$-\mathrm{Mg}$ & $24.8 \mathrm{~ns}$ & $0.134 \mathrm{~ns}$ & $38.1 \mathrm{~ns}$ & $2.08 \mathrm{~ns}$ & $2.26 \mathrm{~ns}$ \\
$-\mathrm{S}$ & $25.1 \mathrm{~ns}$ & $0.163 \mathrm{~ns}$ & $34.6 \mathrm{~ns}$ & $2.23 \mathrm{~ns}$ & $2.38 \mathrm{~ns}$ \\
$-\mathrm{B}$ & $24.6 \mathrm{~ns}$ & $0.164 \mathrm{~ns}$ & $35.2 \mathrm{~ns}$ & $2.18 \mathrm{~ns}$ & $2.33 \mathrm{~ns}$ \\
CV\% & 14.7 & 33.5 & 8.4 & 5.9 & 10.7 \\
\hline
\end{tabular}

In each column, means followed by + , - or ns either are larger, smaller than the one of the complete treatment, according to Dunnett's test at $5 \%$ level. 
Table 4. Effect of macronutrients and boron deficiencies on TA, TSS, TSS/TA, Vitamin C, pH and pulp coloration (PC) of pineapple "Jupi” fruits.

\begin{tabular}{|c|c|c|c|c|c|c|}
\hline Treatments & TA & TSS & TSS/TA & Vit. C & $\mathrm{pH}$ & $\mathrm{PC}^{*}$ \\
\hline & mg $100 \mathrm{~g}^{-1}$ & ${ }^{0}$ Brix & & ascorbic acid (mg $100 \mathrm{~g}^{-1}$ ) & & \\
\hline Complete & 0.44 & 11.2 & 26.0 & 9.1 & 4.43 & 4.67 \\
\hline$-\mathrm{N}$ & $0.81+$ & $12.6+$ & $16.9-$ & $27.1+$ & $3.60-$ & $1.00-$ \\
\hline$-\mathrm{P}$ & $0.55 \mathrm{~ns}$ & $11.7 \mathrm{~ns}$ & $21.2 \mathrm{~ns}$ & $7.8 \mathrm{~ns}$ & $4.16 \mathrm{~ns}$ & $4.00 \mathrm{~ns}$ \\
\hline$-\mathrm{K}$ & $0.48 \mathrm{~ns}$ & $10.7 \mathrm{~ns}$ & $21.0 \mathrm{~ns}$ & $9.8 \mathrm{~ns}$ & $4.13 \mathrm{~ns}$ & $2.83-$ \\
\hline$-\mathrm{Ca}$ & $0.46 \mathrm{~ns}$ & $11.7 \mathrm{~ns}$ & $25.6 \mathrm{~ns}$ & $8.8 \mathrm{~ns}$ & $4.47 \mathrm{~ns}$ & $4.33 \mathrm{~ns}$ \\
\hline$-\mathrm{Mg}$ & $0.43 \mathrm{~ns}$ & $11.8 \mathrm{~ns}$ & $28.3 \mathrm{~ns}$ & $9.2 \mathrm{~ns}$ & $4.58 \mathrm{~ns}$ & $4.67 \mathrm{~ns}$ \\
\hline$-S$ & $0.49 \mathrm{~ns}$ & $12.8+$ & $26.6 \mathrm{~ns}$ & $13.9 \mathrm{~ns}$ & $4.34 \mathrm{~ns}$ & $4.50 \mathrm{~ns}$ \\
\hline$-B$ & $0.50 \mathrm{~ns}$ & $11.4 \mathrm{~ns}$ & $24.6 \mathrm{~ns}$ & $8.7 \mathrm{~ns}$ & $4.42 \mathrm{~ns}$ & $4.83 \mathrm{~ns}$ \\
\hline CV (\%) & 25.4 & 6.1 & 21.6 & 34.9 & 5.2 & 15.7 \\
\hline
\end{tabular}

In each column, means followed by +, - or ns either are larger, smaller or don't differ from the complete treatment, according to Dunnett's test at $5 \%$ level. * Scale of notes: 1 - pulp white, 2 -pulp white with some yellow; 3 -pulp more white than yellow; 4-pulp more yellow than white; 5-pulp yellow e 6-pulp yellow gold.

with increased dose of $\mathrm{N}$.

The value of $0.44 \%$ TA in complete treatment, was similar to that achieved by [22] [23] of 0.4 and 0.41 to $0.65 \%$ of citric acid, respectively; and that is less than the value of the result of us TA 0.305 CV. Jupi [24].

The TSS value of 11.2 (Table 4) was lower than that obtained by [24] of 13.6 for cv. Jupi. It is likely that during the period of harvest, March to May, the oscillation of temperature and luminosity contributed to TSS levels lower.

The decrease of the TSS/TA interface is associated to high acidity with a deficiency of this relationship is considered the best pineapple maturation index than the acidity and the Brix (TSS) isolated.

Working with cv. Jupi [5] noted reduction in relative brix/acidity with high doses of $\mathrm{N}$, result not obtained in this work.

\subsection{Vit C and $\mathrm{pH}$}

The $\mathrm{N}$ deficiency increased the content of Vit. C in 3 times in relation to the content in the complete treatment and decreased $\mathrm{pH}$ in $18.7 \%$ (Table 4). The concentration of $\mathrm{N}$ was $59.0 \%$ and $60.0 \%$ less than the complete treatment on the flowering and fruit ripening stage, respectively (Table 2).

These increases were also observed for [10] [25] [26]. $\mathrm{N}$ deficiency reduces the synthesis of amino acids and thus of proteins, promoting greater availability of photosynthates to be used in the synthesis of secondary metabolism c4 mpounds, such as Ascorbic acid [20].

The content of Vit. C, in the fruits grown in plants that have received the complete solution, was $9.1 \mathrm{mg} \cdot \mathrm{kg}^{-1}$ lower than that obtained by [26] in the fruits of cv. Pérola $17.65 \mathrm{mg}$ of ascorbic acid per $100 \mathrm{~g}$.

With the results obtained in this study it was observed that it is possible through the operation of fertilizing, produce fruits with higher levels of vitamin c.

The reduction in $\mathrm{pH}$ can be attributed to the accumulation of organic acids, whose values are represented by the TA and Vitamin C, due to the impairment of protein synthesis.

\subsection{Pulp Coloration}

There was a pineapple pulp bleaching under deficiency of $\mathrm{N}$ and $\mathrm{K}$ (Table 4).

In the case of $\mathrm{N}$ deficiency, the clearer the fruit pulp also presented a higher value of TA and an underage relationship TSS/TA, compared to more colorful fruits. For nitrogen, pulp coloration could be indicative of nutritional deficiency.

\subsection{Sensory Analysis}

Fruits grown in $\mathrm{N}$ and $\mathrm{K}$ deficient plants obtained organoleptic acceptance bills significantly lower than those of complete treatment (Table 5). There was no significant difference in the scores to the acceptance of the fruits of 
Table 5. Effect of macronutrients and boron deficiencies in pulp approval test of “Jupi” pineapple fruit.

\begin{tabular}{cc}
\hline Treatments & Sensorial analyse (notes given) \\
\hline Complete & 7.63 \\
$-\mathrm{N}$ & $5.60-$ \\
$-\mathrm{P}$ & 7.33 \\
$-\mathrm{K}$ & $6.40-$ \\
-Ca & 6.70 \\
-Mg & 6.93 \\
$-\mathrm{S}$ & 7.70 \\
$-\mathrm{B}$ & 7.47 \\
Cv (\%) & 20 \\
\hline
\end{tabular}

In line, means followed by +, - or ns either are larger, smaller or don't differ from the complete treatment, respectively, according to Dunnett's test at $5 \%$ level. Test approval: each answer was correspond respectively at: 1 (dislike extremely), 2 (dislike a lot), 3 (dislike moderately), 4 (dislike lightly), 5 (indifferent), 6 (liked lightly), 7 (liked moderately), 8 (liked a lot) e 9 (liked extremely).

pineapple under the deficiencies of $\mathrm{P}, \mathrm{Ca}, \mathrm{Mg}, \mathrm{S}$, and $\mathrm{B}$.

Some tasters found the pineapple pieces produced under $\mathrm{N}$ deficiency, watery, tasteless characteristic of pineapple, salt flavor, high acidity, fibrous, pale coloring and watery, tasteless $\mathrm{K}$, little sweet, little juice. The excess acidity was the most cited characteristic, in the comments of assessors in relation to $\mathrm{N}$ deficiency.

It is likely that the higher acidity and the whitish coloration of the pulp have contributed to the notes attributed to the $-\mathrm{N}$ treatment (Table 4). Consumer preference is for fruits less acidic and more attractive in the external aspect.

\section{Conclusions}

-N deficiency reduced the fruit mass with crown at 57.6\%, 38.7\% in length and sensory acceptance of the fruits, but increased the titratable acidity in $85 \%$; the total soluble solids and vitamin C;

-The fruit mass with crown was reduced by $26.8 \% \mathrm{P}$ deficiency and the fruit length of in $33.7 \%$;

-K deficiency reduced in $22.8 \%$ the fruit mass with crown, $17.5 \%$ the peduncle length, $14.36 \%$ the diameter and sensory acceptance of the fruits;

-The peel thickness was not affected by any deficiency;

-Nitrogen is the nutrient that most influenced the quality of the pineapple "Jupi".

\section{Acknowledgements}

We thank the FAPERJ for their financial support.

\section{References}

[1] Faostat Database http://faostat.fao.org/site/567/default.aspx

[2] Carvalho, V.D. de., Abreu, C.M.P. de and Gonçalves, N.B. (1998) Qualidade e industrialização de abacaxi. Informe Agropecuário, 19 , 67-69.

[3] Veloso, C.A.C., Oeiras, A.H.L., Carvalho, E.J.M. and Souza, F.R.S. (2001) Resposta do abacaxizeiro à adição de nitrogênio, potássio e calcário em latossolo amarelo do nordeste paraense. Revista Brasileira Fruticultura, 23, 396-402. http://dx.doi.org/10.1590/S0100-29452001000200040

[4] Silva, A.L.P. da, Silva, A.P. da, Souza, A.P. de, Santos, D., Silva, S. de M. and Silva, V.B. da. (2012) Resposta do abacaxizeiro "Vitória" a doses de nitrogênio em solos de tabuleiros costeiros da Paraíba. Revista Brasileira de Ciência do Solo, 36, 447-456. http://dx.doi.org/10.1590/S0100-06832012000200014 
[5] Coelho, R.I., Lopes, J.C., Carvalho, A.J.C. de, Amaral, J.A.T. do and Matta, F. de P. (2007) Estado nutricional e características de crescimento do abacaxizeiro Jupi cultivado em Latossolo amarelo distrófico em função da adubação com NPK. Ciência e Agrotecnologia, 31, 1696-1701. http://dx.doi.org/10.1590/S1413-70542007000600014

[6] Mengel, K. and Kirkby, E.A. (1987) Principles of Plant Nutrition. 4th Edition, International Potash Institute, Berne, 687p.

[7] Chitarra, M.I. and Chitarra, A.B. (1990) Pós colheita de frutas e hortaliças: Fisiologia e manuseio. ESAL/FAEPE, Lavras, 289p.

[8] Malavolta, E., Vitti, G.C. and Oliveira, A.S. (1997) Avaliação do estado nutricional das plantas: Princípios e aplicações. 2nd Edition, Piracicaba, Potafós, 319p.

[9] Guarçoni, M.A. and Ventura, J.A. (2011) Adubação N-P-K e o desenvolvimento, produtividade e qualidade dos frutos do abacaxi “Gold” MD-2. Revista Brasileira de Ciência do Solo, 35, 1367-1376. http://dx.doi.org/10.1590/S1413-70542007000600014

[10] Spironello, A., Quaggio, J.A., Teixeira, L.A.J., Furlani, R. and Sigrist, J.M.M. (2004) Pineapple Yield and Fruit Quality Effect by NPK Fertilization. Revista Brasileira de Fruticultura, 26, 155-159. http://dx.doi.org/10.1590/S0100-29452004000100041

[11] Silva, A.P., Alvarez V., V.H., Souza, A.P., Neves, J.C.L., Novais, R.F. and Dantas, J.P. (2009) Sistema de recomendação de fertilizantes e corretivos para a cultura do abacaxizeiro. Revista Brasileira de Ciência do Solo, 33, 1269-1280. http://dx.doi.org/10.1590/S0100-06832009000500020

[12] Alves, A. de A., Reinhardt, D.H., Alcantara, J. dos P., Souza, L. F. da S.and Caldas, R.C. (1998) Manejo e avaliação da soca de abacaxi "Pérola” nas condições do semi-árido de Itaberaba, Bahia. Revista Brasileira de Fruticultura, 20, 323-331.

[13] Chitarra, M.I.F. and Chitarra, A.B. (2005) Qualidade pós-colheita de frutos e hortaliças: Fisiologia e manuseio. ESAL/FAEPE, Lavras, 783p.

[14] CQH (Centro de Qualidade em Horticultura-CEAGESP). Programa brasileiro para modernização da horticultura. Normas de Classificação do Abacaxi. São Paulo: CEAGESP, (CQH. Documentos, 24, 2003).

[15] Freitas, N.C. de (2003) Crescimento e produção do abacaxizeiro Pérola, com mudas tipo Filhote, em Dom Aquino-MT. M.Sc. Dissertation, Cuiabá, Universidade Federal de Mato Grosso, 90p.

[16] Spironello, A., Bortoletto, N., Sigrist, J.M.M. and Nagai, V. (1997) Avaliação agrotecnológica e do ciclo de variedades de abacaxizeiro, em duas densidades em Votuporanga (SP). Bragantia, 56, 343-355. http://dx.doi.org/10.1590/S0006-87051997000200013

[17] Abreu, C.M.P., Carvalho, V.D. and Gonçalves, N.B. (1998) Cuidados Pós-colheita e qualidade do abacaxi para exportação. Informe Agropecuário. Belo Horizonte, 19, 5-6.

[18] Bhugaloo, R.A., Lalouette, J.A., Bachraz, D.Y. and Sukerdeep, N. (1999) Effect of Different Levels of Nitrogen on Yield and Quality of Pineapple Variety Queen Victoria. Annual Meeting of Agricultural Scientists, 3, 75-80.

[19] Neto, M.B., Choairy, A.S., de Lacerda, J.T., dos Santos, E.S. and Oliveira, E.F. (1998) Caracterização do abacaxizeiro Pérola no Estado da Paraíba. Pesquisa Agropecuária, Abacaxi, João Pessoa, EMEPA-PB, 33-39.

[20] Marschner, H. (1995) Mineral Nutrition of Higher Plants. Academic Press, London, 889p.

[21] Teixeira, L.A.J., Spironello, A., Furlani, P.R. and Sigrist, J.M.M. (2002) Parcelamento da adubação NPK em abacaxizeiro. Revista Brasileira de Fruticultura, Jaboticabal, 24, 219-224.

[22] Bengozi, I.J., Sampaio, A.C., Spotom, H.F., Mischam, M.M. and Pallamim, M.L. (2007) Qualidades físicas e químicas do abacaxi na CEAGESP de São Paulo. Revista Brasileira de Fruticultura, Jaboticabal, 29, 494-499.

[23] Pereira, M.A.B., Siebeneichler, S.C., Lorençoni, R., Adorian, da Silva, J.C., Garcia, R.B.M., et al. (2009) Qualidade do fruto de abacaxi comercializado pela Cooperfruto-Miranorte-TO. Revista Brasileira de Fruticultura, 31,1048-1053. http://dx.doi.org/10.1590/S0100-29452009000400018

[24] Cunha, G.A.P. da, Cabral, J.R.S, Matos, A.P. de and Caldas, R.C. (2007) Avaliação de genótipos de abacaxi resistentes à fusariose em Coração de Maria, Bahia. Magistra, 19, 219-223.

[25] Lee, S.K. and Kader, A.A. (20000 Preharvest and Post-Harvest Factors Influencing Vitamin C Content of Horticultural Crops. Postharvest Biology and Technology, 20, 207-220. http://dx.doi.org/10.1016/S0925-5214(00)00133-2

[26] Reinhardt, D.H., Medina, V.M., Caldas, R.C., Cunha, G.A.P. da and Estevam, R.F.H. (2004) Gradientes de qualidade em abacaxi "Pérola” em função do tamanho e do estádio de maturação do fruto. Revista Brasileira de Fruticultura, Jaboticabal, 26, 544-546. 